\title{
Pemberian Dosis Pupuk Kandang dan Interval Panen terhadap Produksi Jawer Kotok (Coleus atropurpureus L. Benth)
}

\author{
Manure Fertilizer Rates and Harvesting Interval Application on Jawer Kotok Production \\ (Coleus atropurpureus L. Benth)
}

\author{
Krisetya Ayunina dan Sandra Arifin Aziz* \\ Departemen Agronomi dan Hortikultura, Fakultas Pertanian, Institut Pertanian Bogor \\ (Bogor Agricultural University), Jl. Meranti, Kampus IPB Darmaga, Bogor 16680, Indonesia \\ Telp.\& Faks. 62-251-8629353 e-mail agrohort@ apps.ipb.ac.id \\ *Penulis Korespondensi: sandra.a.aziz@gmail.com \\ Disetujui: 30 Oktober 2018 / Published Online 06 Mei 2019
}

\begin{abstract}
Jawer Kotok is a medicinal plant originated from Indonesia. Jawer Kotok is beneficial to health, but this plant is still not renowned and rarely cultivated. The optimum production of Jawer Kotok needs consideration from plant productivity aspect and its bioactive compound. Cultivating medicinal plants usually executed organically to avoid the chemical effectto the bioactive compound. This research purpose isto find the manure fertilizer rates and harvesting interval effects to Jawer Kotok production as medicinal plant. This research took place in Cikabayan Research Estate, Bogor, West Java, Indonesia from January to July 2018. The design used is Randomized Complete Block Design with 3 blocks. The result shows that manure rates significantly increased total stem wet weight, and growth variables plant height increment, plant canopy width and branch number. Short harvesting interval significantly decreased total leaf wet weight, and growing variables such as leaf number, plant height increment, plant canopy width, branch number, water content and leaf stem percentage. Chlorophyll-a, caroten, and total chlorophyll significantly decreased short harvesting interval. There is an interaction between manure fertilizer rates and harvesting interval towards plant heights increment at 10 and 26 week after planting.
\end{abstract}

Keywords: harvesting age, lamiaceae, leaf pigmen, medicinal plants, miana

\section{ABSTRAK}

Jawer Kotok merupakan tanaman obat yang berasal dari Indonesia. Tanaman ini memiliki berbagai khasiat untuk kesehatan, tetapi belum banyak diketahui dan dibudidayakan sebagai tanaman obat. Produksi Jawer Kotok yang optimum memerlukan pertimbangan dari segi produktivitas tanaman serta bahan aktif yang terkandung di dalamnya. Budidaya tanaman obat umumnya dilakukan secara organik untuk menghindari pengaruh bahan kimia pada senyawa bioaktif dalam tanaman. Penelitian ini dilakukan untuk mengetahui dosis pupuk kandang dan interval panen yang dapat menunjang produksi Jawer Kotok sebagai tanaman obat. Penelitian dilaksanakan di Kebun Percobaan Cikabayan, Bogor, Jawa Barat, Indonesia pada bulan Januari hingga Juli 2018. Rancangan lingkungan yang digunakan adalah Rancangan Kelompok Lengkap Teracak dengan tiga ulangan. Hasil penelitian menunjukkan bahwa dosis pupuk signifikan meningkatkan bobot basah batang total serta variabel pertumbuhan berupa pertambahan tinggi tanaman, lebar tajuk dan jumlah cabang. Interval panen yang sering signifikan menurunkan bobot basah daun total dan variabel pertumbuhan berupa jumlah daun, pertambahan tinggi tanaman, lebar tajuk, jumlah cabang, kadar air, dan persentase daun batang. Interval panen signifikan menurunkan kadar klorofil a, karoten, dan total klorofil daun. Terdapat interaksi antara dosis pupuk dan interval panen pada parameter pertambahan tinggi tanaman pada 10 dan 26 MST.

Katakunci: lamiaceae, miana, pigmen daun, tanaman obat, umur panen 


\section{PENDAHULUAN}

Jawer Kotok (Coleus atropurpureus L. Benth.) merupakan tanaman asli Jawa dan Malaya (Johnson, 1998). Tanaman ini diketahui memiliki khasiat kesehatan diantaranya sebagai anti kanker karena memiliki aktifitas antioksidan yang baik (Nugraheni et al., 2011). Jawer Kotok juga diketahui memiliki aktivitas tabir surya yang baik (Amrillah et al., 2015). Jawer Kotok telah digunakan sebagai obat sakit kepala dan menyembuhkan luka. Kandungan kimia yang ada di dalam Jawer Kotok diantaranya flavonoid dan diterpens yang memiliki aktivitas anti bakteri ringan (Ragasa et al., 2001). Selain manfaatnya sebagai tanaman obat, tanaman ini juga terkenal sebagai tanaman hias karena penampilan daunnya yang unik dan menarik.

Jawer Kotok dapat tumbuh baik pada area yang terpapar sinar matahari langsung dengan drainase yang baik. Jawer Kotok tumbuh optimal pada tanah dengan ketinggian 300-1 $800 \mathrm{~m}$ dpl. Perbanyakan tanaman Jawer Kotok dilakukan dengan stek batang atau stek akar (Soni dan Singhai, 2012). Tanaman ini mudah dibudidayakan di Indonesia karena kondisi agroklimat di Indonesia memenuhi kriteria tumbuh Jawer Kotok. Jawer Kotok merupakan tanaman yang telah dikenal secara umum oleh masyarakat Indonesia dan mudah dijumpai di pekarangan warga.

Produksi Jawer Kotok yang tinggi memerlukan kecukupan hara yang dapat ditunjang melalui pemupukan. Tanaman obat sebaiknya dipupuk dengan menggunakan pupuk organik karena penggunaan pupuk anorganik dikhawatirkan akan memberikan dampak perubahan farmakologis bagi tanaman obat (Winarto, 2003). Interval panen berpengaruh terhadap produksi berbagai zat pada tanaman. Taufika et al. (2016) menyatakan bahwa semakin lama interval panen semakin meningkat produksi protein, flavonoid, antosianin, dan aktivitas enzim PAL pada daun tanaman kemuning, sehingga penentuan interval panen yang tepat dapat meningkatkan produksi Jawer Kotok.

Jawer Kotok adalah tanaman yang bermanfaat dan cocok dikembangkan di Indonesia, tetapi tanaman ini belum banyak dikembangkan dan dibudidayakan secara masal. Jawer Kotok pada umumnya ditanam sebagai tanaman pekarangan dan bukan merupakan komoditas yang diusahakan. Belum adanya budidaya Jawer Kotok secara masal membuat tanaman ini belum memiliki standar operasional prosedur yang baku dalam praktik budidayanya. Penelitian bertujuan mengetahui pengaruh pemberian dosis pupuk, interval panen, serta interaksi kedua faktor terhadap produksi Jawer Kotok (Coleus atropurpureus L. Benth).

\section{BAHAN DAN METODE}

Penelitian dan pembibitan dilaksanakan di Kebun Percobaan Cikabayan, Institut Pertanian Bogor, Dramaga, Bogor pada bulan Januari 2018 hingga bulan Juli 2018. Pengujian hasil dilakukan pada Laboratorium Pasca Panen Departemen Agronomi dan Hortikultura, Fakultas Pertanian, Institut Pertanian Bogor.

Bahan yang digunakan adalah stek batang Jawer Kotok, pupuk kandang sapi dan pupuk kandang kambing. Bibit stek batang Jawer Kotok didapatkan di Dramaga, Kabupaten Bogor. Alat yang digunakan adalah alat ukur massa (timbangan), alat ukur panjang (mistar dan meteran), alat potong (gunting), spektrofotometer, oven dan cooling box.

Penelitian dilakuan dengan menggunakan Rancangan Faktorial dengan rancangan lingkungan Rancangan Kelompok Lengkap Teracak (RKLT). Terdapat dua faktor dalam penelitian ini yaitu dosis pupuk kandang dan interval panen. Faktor pertama merupakan dosis penggunaan campuran pupuk kandang sapi dan kambing dengan perbandingan 1:1 yaitu 0,9 , 13.5, dan 18 ton hektar-1. Faktor kedua merupakan interval panen yang meliputi panen 1, 2, dan 3 bulan sekali. Terdapat 2 faktor dengan masingmasing memiliki taraf perlakuan 3 dan 4 taraf sehingga terdapat total 12 kombinasi. Perlakuan dilakukan pada 3 kelompok dengan masingmasing 5 tanaman tiap kombinasi, sehingga populasi tanaman contoh yang digunakan adalah 180 tanaman.Untuk menghindari efek tanaman pinggir maka pada petak percobaan ditambahkan tanaman pinggir di luar tanaman percobaan.

Bibit didapatkan dari desa di Dramaga, Bogor. Stek diambil dari tanaman yang telah tumbuh dengan memotong batangnya dan menyisakan beberapa helai daun. Setelah didapatkan stek yang diinginkan dilakukan pembibitan selama satu bulan dalam polibag dengan media tanah hingga akar terinisiasi. Pengolahan lahan dilakukan dengan melakukan pembabatan gulma, dilanjutkan dengan penggemburan tanah dengan traktor. Setelah tanah menjadi rata dan gembur dibuat lubang tanam dengan menambahkan pupuk kandang sesuai dengan dosis perlakuan. Stek hasil pembibitan ditanam di lahan dengan jarak tanam $1 \mathrm{~m} \mathrm{x} 1 \mathrm{~m}$. Tanaman disiram secara berkala dengan alat siram secara manual hingga tanah cukup lembab. Pengendalian gulma dilakukan pada saat 
diperlukan. Pupuk diberikan pada 2 bulan setelah tanam (BST) dan 4 BST dengan dosis masingmasing setengah dosis perlakuan.

Pengendalian hama dilakukan pada saat pembibitan dan penanaman di lapang. Pestisida yang digunakan adalah pestisida nabati. Pestisida nabati yang digunakan terbuat dari bawang putih, kunyit, lengkuas, serai, dan lada. Bawang putih memiliki kemampuan sebagai pengusir serangga karena bawang putih mengandung senyawa bersifat asam (Saenong, 2016). Serai mengandung $35 \%$ citronella, citronella mampu membuat serangga mengalami dehidrasi sehingga dapat membunuh serangga. Selain itu daun serai bersifat repellent serangga, insektisida, bakterisida, dan nematosida (Herminanto et al., 2010). Kunyit dan lengkuas mengandung senyawa minyak atsiri, sineol, dan alkaloid yang berperan sebagai fungisida nabati (Paramitasari, 2011). Lada mengandung piperlonguminie dan piperine yang berfungsi sebagai insektisida pada stadium larva dan dewasa dari $L$. decemlineata pada tanaman kentang (Scott et al., 2003). Bawang putih 1 ons, kunyit 1 ons, lengkuas 3 ons, 3 batang serai, dan merica secukupnya dihaluskan dan dicampur.Setelah semua bahan halus dan tercampur rata, bahan direbus hingga mendidih lalu disaring ampasnya. Air rebusan ini diaplikasikan pada permukaan tanaman yang terserang hama.

Panen dilakukan dengan cara memotong tajuk tanaman dari jarak tertentu di atas tanah, Untuk panen bulan pertama dilakukan pemotongan tajuk $20 \mathrm{~cm}$ dari atas tanah, bulan berikutnya panen dilakukan dengan memangkas tajuk $25 \mathrm{~cm}$ dari atas tanah dan terus bertambah 5 $\mathrm{cm}$ setiap bulan hingga bulan ke-enam. Pemanenan memperhatikan kondisi tanaman di lapang apakah sudah cukup layak untuk dipanen atau tidak.

Pengamatan dilakukan terhadap komponen produksi daun Jawer Kotok berupa jumlah daun, tinggi dan pertambahan tinggi tanaman, lebar tajuk, jumlah cabang, bobot basah panen, bobot kering panen (tajuk, daun, dan batang), uji kadar pigmen klorofil a, klorofil b, karotenoid, antosianin, dan total klorofil daun. Pengamatan jumlah daun, tinggi tanaman, lebar tajuk, dan jumlah cabang dilakukan 2 minggu sekali. Pengamatan pigmen daun dilakukan pada tanaman umur 4 BST.

Data dianalisis dengan uji $\mathrm{F}$ pada taraf nyata $5 \%$ untuk mengetahui adanya pengaruh perlakuan dengan menggunakan program SAS 9.0. Jika terdapat perbedaan yang nyata maka dilakukan uji lanjut Duncan Multiple Range Test (DMRT) pada taraf nyata 5\%.

\section{HASIL DAN PEMBAHASAN}

Terdapat 4 parameter yang diamati yaitu parameter pertumbuhan berupa jumlah daun, pertambahan tinggi tanaman, lebar tajuk, dan jumlah cabang. Parameter yang kedua yaitu parameter hasil yang meliputi bobot basah dan kering panen, serta kadar pigmen klorofil a, klorofil b, karotenoid, antosianin, dan total klorofil. Faktor dosis pupuk berpengaruh pada jumlah daun pada umur 26 minggu setelah tanam (MST), lebar tajuk pada umur 18 sampai 26 MST, dan jumlah cabang pada 16 MST. Interval panen berpengaruh pada jumlah daun pada umur 14 dan 26 MST, pertambahan tinggi tanaman mulai umur 10 hingga 26 MST, lebar tajuk mulai umur 18 sampai 26 MST, dan jumlah cabang pada 22 MST. Interaksi antara faktor dosis pupuk dan interval panen terjadi pada parameter pertambahan tinggi tanaman pada 10 dan 26 MST (Tabel 2). Hasil panen jawer kotok secara total menunjukkan adanya pengaruh nyata pada faktor dosis pupuk pada bobot basah batang dan interval panen pada bobot basah daun (Tabel 1).

\section{Jumlah Daun}

Pada 14 MST interval panen 2 bulan sekali meningkatkan jumlah daun sebesar 26 dan $28 \%$ dibandingkan interval panen 1 dan 3 bulan sekali. Pada 26 MST interval panen 1 bulan sekali meningkatkan jumlah daun sebesar 36 dan $25 \%$ dari interval panen 2 dan 3 bulan sekali (Tabel 2). Tanaman dengan interval panen 1 dan 2 bulan sekali mengalami pemangkasan lebih sering dari interval panen 3 bulan sekali. Menurut Rochayat et al. (2017) saat tanaman dipangkas, asimilat terkonsentrasi pada bagian atas untuk membentuk cabang. Cabang yang terbentuk menginisiasi pembentukan daun karena aktifnya kuncup dorman pada bagian lateral. Tanaman yang mendapatkan perlakuan interval panen 1 dan 2 bulan sekali memiliki umur daun yang lebih muda dari tanaman dengan interval panen 3 bulan sekali. Hasan et al. (2017) menyatakan bahwa

Tabel 1. Nilai rata-rata interval panen terhadap jumlah daun

\begin{tabular}{lrrr}
\hline Perlakuan & \multicolumn{3}{c}{ Jumlah Daun } \\
\cline { 2 - 4 } Interval Panen & 2 MST & 14 MST & 26 MST \\
\hline 1 bulan sekali & 10.72 & $398.22 \mathrm{~b}$ & $699.23 \mathrm{a}$ \\
2 bulan sekali & 10.65 & $541.03 \mathrm{a}$ & $442.82 \mathrm{~b}$ \\
3 bulan sekali & 9.81 & $385.44 \mathrm{~b}$ & $522.97 \mathrm{~b}$ \\
\hline
\end{tabular}

Keterangan: $\mathrm{MST}=$ minggu setelah tanam; Angka yang diikuti huruf yang berbeda pada kolom yang sama untuk masing-masing jumlah daun menunjukkan perbedaan nyata berdasarkan uji Duncan pada taraf nyata $\alpha=5 \%$ 
daun yang lebih muda menyerap $\mathrm{N}$ lebih banyak, sehingga pertumbuhannya lebih cepat. Pertambahan jumlah daun yang tinggi diinsiasi oleh aktifnya tunas lateral serta penyerapan $\mathrm{N}$ yang tinggi oleh daun berumur muda.

Pada tanaman berumur 14 MST tanaman dengan interval panen 2 bulan sekali memiliki jumlah daun lebih banyak dari jumlah daun tanaman dengan interval panen 1 bulan sekali, hal ini tidak sejalan dengan pemahaman semakin sering interval panen semakin banyak jumlah daun. Januwati et al. (1996) menyatakan bahwa pemangkasan pada umur tanaman yang lebih muda menghambat pertumbuhan apikal dan pembentukan beberapa hormon pertumbuhan sehingga jumlah daun lebih sedikit.
Tanaman mengalami panen berupa pemangkasan pada $8,12,16,20$ dan 24 MST. Pada 14 MST tanaman dengan interval panen 1 bulan sekali mengalami 2 kali panen sehingga jumlah daunnya lebih sedikit dari interval panen 2 bulan sekali. Pengaruh pertumbuhan tunas lateral pada jumlah daun baru terlihat pada 26 MST (Tabel 2).

\section{Pertambahan Tinggi Tanaman}

Dosis pupuk kandang 18 ton hektar-1 memberikan hasil pertambahan tinggi tanaman yang lebih besar dari dosis pupuk kandang 0, 9, dan 13.5 ton hektar ${ }^{-1}$ sebesar berturut-turut 45.43 dan $65 \%$. Hal ini sejalan dengan penelitian Usboko et al. (2017) yang menyatakan dosis

Tabel 2. Rekapitulasi hasil sidik ragam untuk parameter pertumbuhan tanaman dan hasil

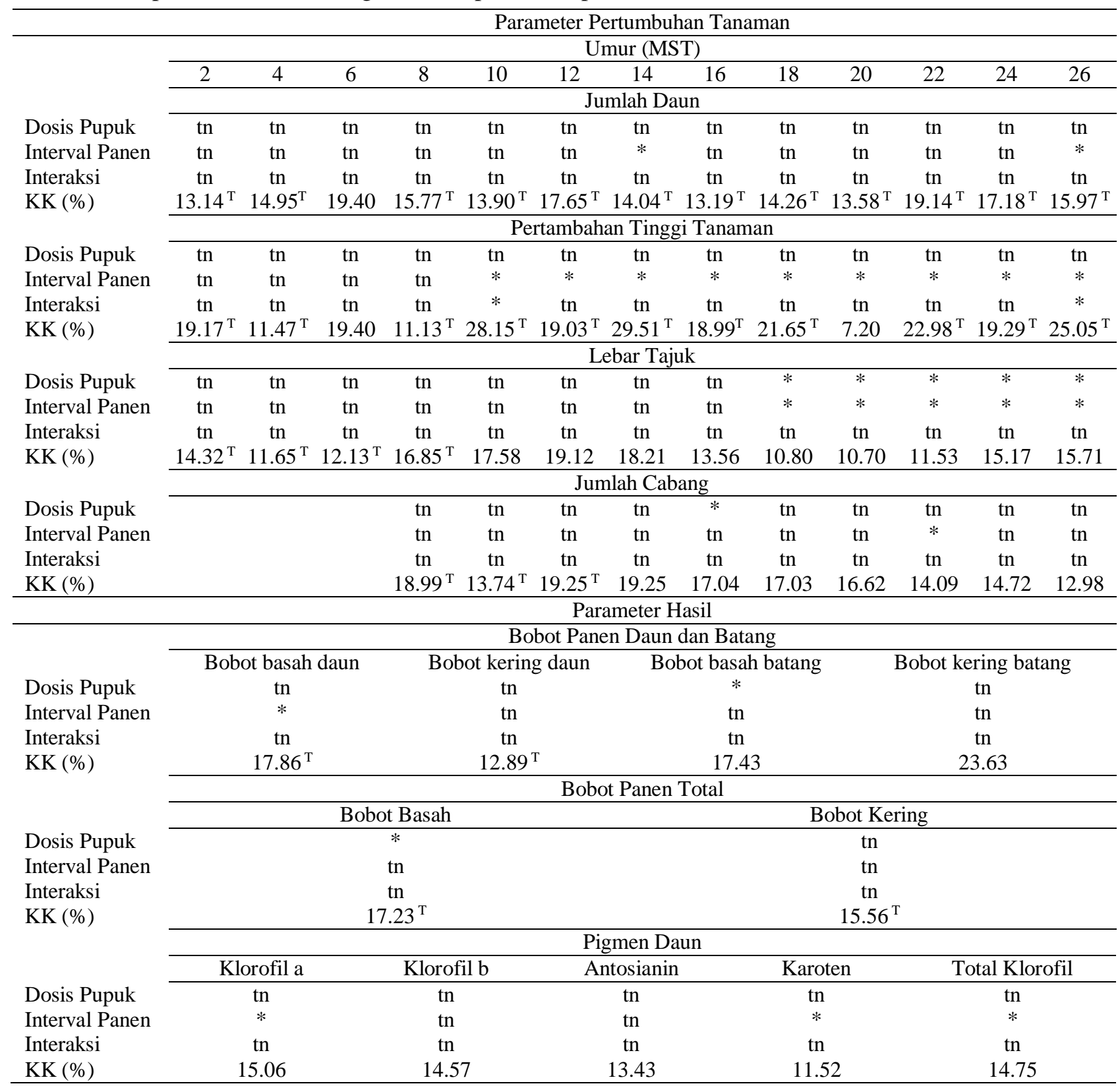

Keterangan: KK= Koefisien Keragaman; * = nyata menurut uji F; ${ }^{\mathrm{T}}=$ telah dilakukan transformasi data dengan rumus $\sqrt{\mathrm{x}+0.5}$ 
pupuk kandang nyata meningkatkan tinggi tanaman kacang buncis, tetapi pengaruhnya baru nyata pada pengamatan 28 hari setelah tanam akibat sifat pupuk kandang yang lambat tersedia. Dosis pupuk 0, 9, dan 13.5 ton hektar ${ }^{-1}$ menunjukkan kurangnya hara yang disediakan melalui pupuk kandang bagi tanaman yang telah mengalami 5 kali panen. Pemberian dosis pupuk kandang baru terlihat pengaruhnya terhadap pertambahan tinggi tanaman pada minggu terakhir pengamatan (26 MST) (Tabel 3).

Tabel 3. Nilai rata-rata dosis pupuk terhadap pertambahan tinggi tanaman

\begin{tabular}{ccc}
\hline $\left.\begin{array}{c}\text { Dosis Pupuk } \\
\text { (ton hektar }\end{array}{ }^{-1}\right)$ & \multicolumn{2}{c}{ Pertambahan Tinggi Tanaman $(\mathrm{cm})$} \\
\cline { 2 - 3 } & $2 \mathrm{MST}$ & $26 \mathrm{MST}$ \\
\hline 0 & 8.07 & $3.78 \mathrm{~b}$ \\
13.5 & 6.97 & $3.91 \mathrm{~b}$ \\
18 & 6.46 & $2.43 \mathrm{~b}$ \\
\hline
\end{tabular}

Keterangan: $\mathrm{MST}=$ minggu setelah tanam; Angka yang diikuti huruf yang berbeda pada kolom yang sama untuk masing-masing pertambahan tinggi tanaman menunjukkan perbedaan nyata berdasarkan uji Duncan pada taraf nyata $\alpha=5 \%$

Interval panen 3 bulan sekali meningkatkan pertambahan tinggi tanaman sebesar 50 dan 52\% dari interval panan 1 dan 2 bulan pada 10 MST, sementara pada 12 MST interval panen 3 bulan sekali meningkatkan pertambahan tinggi tanaman sebesar $42 \%$ dan $33 \%$ dari interval panen 1 dan 2 bulan sekali. Pada umur 12 MST tanaman dengan perlakuan interval panen 3 bulan sekali mengalami panen sehingga pertambahan tinggi pada 14 MST tidak berbeda nyata dengan interval panen 2 bulan sekali (Tabel 4). Pertambahan tinggi tanaman pada 16 dan 20 MST perlakuan interval panen 3 bulan sekali menjadi lebih rendah dari 2 bulan sekali. Hal ini karena panen pada 12 MST membuat pertumbuhan tanaman menurun akibat hilangnya tunas apikal. Esrita (2012) mengungkapkan bahwa pemangkasan tunas apikal yang sering dapat menyebabkan penurunan pertambahan tinggi tanaman. Pada 22 MST interval panen 3 bulan sekali menunjukkan pertambahan tinggi tanaman yang lebih rendah dari interval panen 1 dan 2 bulan sekali. Hal ini diduga karena adanya pengaruh lingkungan berupa kondisi cuaca. Pada akhir pengamatan interval panen 3 bulan sekali meningkatkan pertambahan tinggi tanaman 46 dan $48 \%$ dari interval panen 1 dan 2 bulan sekali.

Terdapat interaksi antara dosis pupuk dengan interval panen pada 10 dan 26 MST yang ditunjukkan pada Tabel 5. Pada 10 MST interval panen 3 bulan sekali pada semua taraf dosis pupuk menunjukkan pertambahan tinggi tanaman paling besar. Pada 26 MST dosis pupuk 18 ton hektar ${ }^{-1}$ pada semua taraf interval panen menunjukkan pertambahan tinggi tanaman yang paling besar.

Tabel 5. Interaksi antara dosis pupuk dengan interval panen terhadap pertambahan tinggi tanaman

\begin{tabular}{lcccr}
\hline \multirow{2}{*}{$\begin{array}{l}\text { Waktu } \\
\text { (MST) }\end{array}$} & $\begin{array}{c}\text { Dosis } \\
\text { Pupuk (ton } \\
\left.\text { hektar }^{-1}\right)\end{array}$ & \multicolumn{4}{c}{ Interval Panen (bulan sekali) } \\
\cline { 3 - 5 } 10 & & $\ldots \ldots \ldots \ldots \ldots(\mathrm{cm}) \ldots \ldots \ldots \ldots \ldots$. \\
& 0 & $2.80 \mathrm{~b}$ & $10.86 \mathrm{a}$ & $9.45 \mathrm{a}$ \\
& 9 & $2.61 \mathrm{~b}$ & $3.56 \mathrm{ab}$ & $2.00 \mathrm{a}$ \\
& 13.5 & $2.00 \mathrm{a}$ & $1.17 \mathrm{~b}$ & $11.47 \mathrm{a}$ \\
26 & 18 & $4.76 \mathrm{ab}$ & $4.38 \mathrm{ab}$ & $8.55 \mathrm{a}$ \\
\cline { 2 - 5 } & 0 & $4.50 \mathrm{a}$ & $2.86 \mathrm{a}$ & $4.00 \mathrm{~b}$ \\
& 9 & $3.30 \mathrm{a}$ & $2.56 \mathrm{a}$ & $5.86 \mathrm{~b}$ \\
& 13.5 & $2.00 \mathrm{a}$ & $2.56 \mathrm{a}$ & $2.73 \mathrm{~b}$ \\
& 19 & $3.53 \mathrm{a}$ & $4.83 \mathrm{a}$ & $12.41 \mathrm{a}$ \\
\hline
\end{tabular}

Keterangan: MST $=$ minggu setelah tanam; Angka yang diikuti huruf yang berbeda pada kolom yang sama untuk masing-masing pertambahan tinggi tanaman menunjukkan perbedaan nyata berdasarkan uji Duncan pada taraf nyata $\alpha=5 \%$

\section{Lebar Tajuk}

Pemberian dosis pupuk kandang 18 ton hektar ${ }^{-1}$ meningkatkan $21 \%$ lebar tajuk dari pada tanpa diberi pupuk kandang (Tabel 6). Hal ini sesuai dengan penelitian Sulistianingrum (2015) yang menyatakan bahwa dosis pupuk organik berupa pupuk kandang sapi signifikan meningkatkan diameter tanaman cengkih, tetapi pengaruh dosis pupuk baru terilhat pada 4 MST akibat sifat pupuk kandang yang lambat tersedia. Pemberian dosis pupuk kandang baru terlihat pengaruhnya pada 18 MST hingga akhir pengamatan. Pada 26 MST interval panen 0,9 , dan 13.5 ton hektar ${ }^{-1}$ memiliki lebar tajuk yang tidak berbeda, diduga tanaman mulai kekurangan hara dan perlu dipupuk kembali.

Tabel 4. Nilai rata-rata interval panen terhadap pertambahan tinggi tanaman

\begin{tabular}{lrrrrrrrrr}
\hline \multirow{2}{*}{ Interval Panen } & \multicolumn{10}{c}{ Pertambahan tinggi tanaman $(\mathrm{cm})$} \\
\cline { 2 - 10 } & \multicolumn{1}{c}{10} & 12 & \multicolumn{1}{c}{14} & \multicolumn{1}{c}{16} & \multicolumn{1}{c}{20} & 22 & 24 & 26 \\
\hline 1 bulan sekali & 6.55 & $5.23 \mathrm{~b}$ & $6.51 \mathrm{~b}$ & $3.42 \mathrm{~b}$ & $6.91 \mathrm{ab}$ & $20.86 \mathrm{~b}$ & $26.63 \mathrm{~b}$ & $3.03 \mathrm{~b}$ & $3.33 \mathrm{~b}$ \\
2 bulan sekali & 7.47 & $5.00 \mathrm{~b}$ & $7.55 \mathrm{~b}$ & $14.75 \mathrm{a}$ & $9.90 \mathrm{a}$ & $25.10 \mathrm{a}$ & $52.27 \mathrm{a}$ & $11.78 \mathrm{a}$ & $3.20 \mathrm{~b}$ \\
3 bulan sekali & 7.85 & $10.62 \mathrm{a}$ & $11.29 \mathrm{a}$ & $12.41 \mathrm{a}$ & $6.14 \mathrm{~b}$ & $21.92 \mathrm{~b}$ & $16.49 \mathrm{c}$ & $10.30 \mathrm{a}$ & $6.25 \mathrm{a}$ \\
\hline
\end{tabular}

Keterangan: MST = minggu setelah tanam; Angka yang diikuti huruf yang berbeda pada kolom yang sama untuk masingmasing pertambahan tinggi tanaman menunjukkan perbedaan nyata berdasarkan uji Duncan pada taraf nyata $\alpha=5 \%$ 
Tabel 6. Nilai rata-rata dosis pupuk kandang terhadap lebar tajuk

\begin{tabular}{ccccll}
\hline Dosis Pupuk Kandang & \multicolumn{5}{c}{ Lebar Tajuk $(\mathrm{cm})$} \\
\cline { 2 - 6 }$\left(\right.$ ton hektar $\left.^{-1}\right)$ & 18 & 20 & 22 & 24 & 26 \\
\hline 0 & $95.49 \mathrm{c}$ & $97.44 \mathrm{c}$ & $99.40 \mathrm{c}$ & $110.60 \mathrm{c}$ & $121.31 \mathrm{~b}$ \\
9 & $99.58 \mathrm{bc}$ & $101.57 \mathrm{bc}$ & $112.20 \mathrm{~b}$ & $117.97 \mathrm{~b}$ & $125.29 \mathrm{~b}$ \\
13.5 & $109.86 \mathrm{ab}$ & $111.95 \mathrm{ab}$ & $122.45 \mathrm{~b}$ & $126.24 \mathrm{ab}$ & $135.48 \mathrm{ab}$ \\
18 & $114.84 \mathrm{a}$ & $116.98 \mathrm{a}$ & $137.53 \mathrm{a}$ & $143.27 \mathrm{a}$ & $154.29 \mathrm{a}$ \\
\hline
\end{tabular}

Keterangan: MST= minggu setelah tanam; Angka yang diikuti huruf yang berbeda pada kolom yang sama untuk masingmasing lebar tajuk menunjukkan perbedaan nyata berdasarkan uji Duncan pada taraf nyata $\alpha=5 \%$

Tabel 7. Nilai rata-rata interval panen terhadap lebar tajuk

\begin{tabular}{ccccccc}
\hline \multirow{2}{*}{ Interval Panen } & \multicolumn{7}{c}{ Lebar Tajuk $(\mathrm{cm})$} \\
\cline { 2 - 7 } & 2 & 18 & 20 & 22 & 24 & 26 \\
\hline 1 bulan sekali & 8.30 & $100.14 \mathrm{~b}$ & $102.14 \mathrm{~b}$ & $108.32 \mathrm{~b}$ & $116.53 \mathrm{~b}$ & $116.70 \mathrm{~b}$ \\
2 bulan sekali & 8.40 & $112.53 \mathrm{a}$ & $114.65 \mathrm{a}$ & $120.15 \mathrm{a}$ & $113.71 \mathrm{~b}$ & $126.83 \mathrm{~b}$ \\
3 bulan sekali & 9.07 & $102.16 \mathrm{~b}$ & $104.17 \mathrm{~b}$ & $125.22 \mathrm{a}$ & $143.31 \mathrm{a}$ & $154.25 \mathrm{a}$ \\
\hline
\end{tabular}

Keterangan: MST= minggu setelah tanam; Angka yang diikuti huruf yang berbeda pada kolom yang sama untuk masing-masing bagian daun menunjukkan perbedaan nyata berdasarkan uji Duncan pada taraf nyata $\alpha=5 \%$

Lebar tajuk dipengaruhi oleh umur panen yang merupakan dampak perbedaan interval panen. Terlihat pada 18 dan 20 MST interval panen 2 bulan sekali meningkatkan 10 dan $9 \%$ lebar tajuk dibandingkan interval 1 dan 3 bulan sekali (Tabel 7). Pada 12 MST terjadi panen yang pertama bagi interval panen 3 bulan sekali, sedangkan interval panen 1 dan 2 bulan sekali telah mengalami panen terlebih dahulu. Menurut Saprudin (2013), pemangkasan pada fase vegetatif akan memicu pertumbuhan tunas dan cabang lateral. Umur tanaman yang tua membuat tunas pada batang bawah menjadi tidak aktif akibat telah lewat masa vegetatifnya.Hal yang sama terjadi pada tanaman dengan interval panen 2 bulan sekali pada umur 24 hingga 26 MST. Panen pada 24 MST membuat tanaman dengan interval panen 2 bulan sekali terhambat pertumbuhannya. Tanaman dengan interval panen 1 bulan sekali selalu lebih rendah lebar tajuknya akibat pemangkasan yang terjadi terus menerus.

\section{Jumlah Cabang}

Dosisi pupuk 18 ton hektar-1 menunjukkan peningkatan jumlah cabang sebesar 25 dan $17 \%$ dari dosis pupuk 9 dan 13.5 ton hektar ${ }^{-1}$, tetapi tidak berbeda untuk tanaman yang tidak dipupuk (Tabel 8). Pengaruh dosis pupuk baru terlihat pada pengamatan 16 MST diduga karena penggunaan pupuk kandang tanpa disertai pupuk kimia memberikan pengaruh yang lambat pada tanaman sehingga tidak dapat dilihat secara cepat pengaruhnya. Hal ini sesuai dengan penelitian Arifah (2013) yang menyatakan pupuk kandang sapi lama penguraiannya dalam tanah dan bersifat dingin, sehingga manfaat pupuk kandang sapi lambat tersedia.

Tabel 8. Nilai rata-rata dosis pupuk kandang terhadap jumlah cabang

\begin{tabular}{cccc}
\hline Dosis & \multicolumn{3}{c}{ Jumlah Cabang } \\
\cline { 2 - 4 } Pupuk $_{\text {ton hektar }}{ }^{-1}$ & 8 & 16 & 26 \\
\hline 0 & 4.64 & $19.04 \mathrm{ab}$ & 16.02 \\
9 & 2.95 & $15.67 \mathrm{c}$ & 14.77 \\
13.5 & 4.75 & $17.20 \mathrm{bc}$ & 14.41 \\
18 & 4.14 & $20.93 \mathrm{a}$ & 16.23 \\
\hline
\end{tabular}

Keterangan: MST = minggu setelah tanam; Angka yang diikuti huruf yang berbeda pada kolom yang sama untuk masing-masing jumlah cabang menunjukkan perbedaan nyata berdasarkan uji Duncan pada taraf nyata $\alpha=5 \%$

\section{Bobot Basah dan Bobot Kering Panen}

Tabel 9 menunjukkan bahwa pemberian dosis pupuk 13.5 ton hektar ${ }^{-1}$ tidak berbeda nyata dengan pemberian dosis pupuk 0,9 , maupun 18 ton hektar-1. Menurut Prasetyo (2014), pemberian pupuk kandang terutama pupuk kandang sapi meningkatkan kadar $\mathrm{N}$ dalam tanah. $\mathrm{N}$ berperan penting dalam pertumbuhan tanaman agar tanaman dapat tumbuh baik. Pupuk kandang sapi juga dapat meningkatkan ketersediaan air dalam tanah sehingga dapat meningkatkan penyerapan air pada tanaman. Pemberian dosis pupuk kandang sebesar 18 ton hektar ${ }^{-1}$ mampu meningkatkan bobot basah batang sebesar $37 \%$ dibanding tanpa pemberian pupuk. Dosis pupuk kandang 18 ton hektar-1 meningkatkan $33 \%$ bobot panen basah dibanding tanpa pemberian pupuk. Pemberian dosis pupuk kandang meningkatkan pertumbuhan beberapa parameter pertumbuhan yang berhubungan dengan batang berupa pertambahan tinggi tanaman pada 
Tabel 9. Nilai rata-rata dosis pupuk terhadap bobot panen total

\begin{tabular}{|c|c|c|c|c|c|c|}
\hline \multirow[b]{2}{*}{$\begin{array}{l}\text { Dosis Pupuk } \\
\text { (ton hektar-1) }^{-1} \text { ) }\end{array}$} & \multicolumn{6}{|c|}{ Bobot Panen (g) } \\
\hline & $\begin{array}{c}\text { Bobot Basah } \\
\text { Daun } \\
\end{array}$ & $\begin{array}{c}\text { Bobot Kering } \\
\text { Daun }\end{array}$ & $\begin{array}{c}\text { Bobot Basah } \\
\text { Batang } \\
\end{array}$ & $\begin{array}{c}\text { Bobot Kering } \\
\text { Batang } \\
\end{array}$ & $\begin{array}{c}\text { Bobot } \\
\text { Basah Total } \\
\end{array}$ & $\begin{array}{c}\text { Bobot Kering } \\
\text { Total } \\
\end{array}$ \\
\hline 0 & 358.45 & 55.73 & $202.77 \mathrm{~b}$ & 19.33 & $561.2 b$ & 77.04 \\
\hline 9 & 375.09 & 57.71 & $225.48 b$ & 24.20 & $601.6 \mathrm{~b}$ & 79.94 \\
\hline 13.5 & 419.00 & 66.87 & $257.22 \mathrm{ab}$ & 23.25 & 676.2ab & 90.13 \\
\hline 18 & 519.64 & 71.42 & $322.01 \mathrm{a}$ & 34.51 & $841.6 \mathrm{a}$ & 105.94 \\
\hline \multicolumn{7}{|l|}{ Interval Panen } \\
\hline 1 bulan sekali & $471.88 \mathrm{a}$ & 62.08 & 217.54 & 18.43 & 759.98 & 98.69 \\
\hline 2 bulan sekali & $459.18 \mathrm{a}$ & 68.70 & 300.80 & 29.99 & 689.42 & 85.57 \\
\hline 3 bulan sekali & $323.83 \mathrm{~b}$ & 58.03 & 237.27 & 27.55 & 561.10 & 80.51 \\
\hline
\end{tabular}

Keterangan: Angka yang diikuti huruf yang berbeda pada kolom yang sama menunjukkan perbedaan nyata berdasarkan uji Duncan pada taraf nyata $\alpha=5 \%$

minggu terakhir pengamatan (26 MST) dan lebar tajuk mulai minggu ke-18 MST hingga akhir pengamatan (Tabel 3 dan 7). Tingginya tanaman serta lebar tajuk tanaman menyebabkan bobot basah batang semakin tinggi.

Interval panen 1 dan 2 bulan sekali meningkatkan 31 dan $29 \%$ bobot basah daundibandingkan interval panen 3 bulan sekali (Tabel 9). Interval panen 1 dan 2 bulan sekali memungkinkan tanaman untuk lebih sering dipangkas (panen) sehingga batang utama menjadi lebih pendek. Menurut Rochayat et al. (2017) saat tanaman dipangkas, asimilat terkonsentrasi pada bagian atas untuk membentuk cabang. Cabang yang terbentuk menginisiasi pembentuk daun karena aktifnya kuncup dorman pada bagian lateral. Jumlah daun pada 14 MST dan 26 MST menunjukkan bahwa interval panen 1 dan 2 bulan sekali memberikan hasil jumlah daun yang lebih tinggi dari interval panen 3 bulan sekali (Tabel 2). Bobot basah daun tertinggi pada interval panen 1 dan 2 bulan sekali disebabkan oleh tingginya pertumbuhan daun yang diinsiasi oleh aktifnya tunas lateral serta penyerapan $\mathrm{N}$ yang tinggi oleh daun berumur muda.

Berbeda dengan kecenderungan yang terjadi pada bobot basah daun total, nilai rata-rata bobot basah dan bobot kering daun pada umur 4 dan 6 BST menunjukkan hal yang berbeda. Pada Tabel 10 terlihat bahwa panen pada umur 4 BST, interval panen 2 bulan sekali menghasilkan bobot kering daun yang lebih tinggi dari interval panen 1 bulan sekali. Pada panen umur 6 BST interval panen 3 bulan sekali menghasilkan bobot basah dan bobot kering daun yang lebih tinggi dari interval panen 2 bulan sekali dan 1 bulan sekali. Hal ini sejalan dengan penelitian Rochayat et al. (2017) yang menunjukkan bahwa semakin panjang batang semakin banyak jumlah daun yang dihasilkan. Meskipun pemangkasan memicu pertumbuhan tunas lateral, tetapi pertumbuhan tunas lateral memerlukan waktu sehingga pada parameter panen di umur 4 dan 6 BST menunjukkan semakin sering tanaman dipangkas semakin sedikit bobot basah daun yang didapatkan. Pengaruh aktifnya tunas lateral pada pertambahan jumlah daun baru terlihat pada minggu terakhir pengamatan yaitu 26 MST (Tabel 1).

Nilai rata-rata bobot basah dan bobot kering batang pada umur 3, 4, dan 6 BST menunjukkan interval panen yang lebih lama memberikan hasil panen rata-rata yang lebih tinggi. Kecuali untuk bobot basah batang pada panen umur 3 BST tidak memperlihatkan perbedaan yang nyata dari kedua interval panen (Tabel 10). Hal ini sejalan dengan persentase antara daun dan batang yang ditunjukkan pada Tabel 10. Persentase bagian yang

Tabel 10. Nilai rata-rata interval panen dan persentase bagian terhadap bobot panen pada 3, 4 dan 6 BST

\begin{tabular}{|c|c|c|c|}
\hline \multirow{2}{*}{ Bobot panen $(\mathrm{g})$} & \multicolumn{3}{|c|}{ Interval Panen (bulan sekali) } \\
\hline & 1 & 2 & 3 \\
\hline & \multicolumn{3}{|c|}{ Panen Daun Umur 4 BST } \\
\hline Bobot basah & $248.49 \mathrm{a}$ & $364.63 \mathrm{a}$ & \\
\hline Bobot kering & $28.41 \mathrm{~b}$ & $55.93 \mathrm{a}$ & \\
\hline \multirow[t]{2}{*}{$\%$ Daun/ panen } & $71 \%$ & $58 \%$ & \\
\hline & \multicolumn{3}{|c|}{ Panen Daun Umur 6 BST } \\
\hline Bobot basah & $16.74 \mathrm{c}$ & $39.87 \mathrm{~b}$ & $207.72 \mathrm{a}$ \\
\hline Bobot kering & $2.75 \mathrm{c}$ & $6.01 \mathrm{~b}$ & $35.82 \mathrm{a}$ \\
\hline \multirow[t]{2}{*}{$\%$ Daun/panen } & $79 \%$ & $72 \%$ & $59 \%$ \\
\hline & \multicolumn{3}{|c|}{ Panen Batang Umur 3 BST } \\
\hline Bobot basah & $64.50 \mathrm{a}$ & & $86.87 \mathrm{a}$ \\
\hline Bobot kering & $4.59 \mathrm{~b}$ & & $10.16 \mathrm{a}$ \\
\hline \multirow[t]{2}{*}{$\%$ Batang/ panen } & $40 \%$ & & $42 \%$ \\
\hline & \multicolumn{3}{|c|}{ Panen Batang Umur 4 BST } \\
\hline Bobot basah & $97.19 \mathrm{~b}$ & $260.51 \mathrm{a}$ & \\
\hline Bobot kering & $8.72 \mathrm{~b}$ & $26.14 \mathrm{a}$ & \\
\hline \multirow[t]{2}{*}{$\%$ Batang/ panen } & $29 \%$ & $42 \%$ & \\
\hline & \multicolumn{3}{|c|}{ Panen Batang Umur 6 BST } \\
\hline Bobot basah & $4.52 \mathrm{~b}$ & $16.38 \mathrm{~b}$ & $150.400 \mathrm{a}$ \\
\hline Bobot kering & $0.42 b$ & $1.42 \mathrm{~b}$ & $17.389 \mathrm{a}$ \\
\hline \%Batang/ panen & $21 \%$ & $28 \%$ & $41 \%$ \\
\hline
\end{tabular}

Keterangan: $\mathrm{BST}=$ bulan setelah tanam; $\%$ Daun $=$ persentase bobot daun dengan bobot total; \%Batang= persentase bobot batang dengan bobot total Angka yang diikuti huruf yang berbeda pada kolom yang sama menunjukkan perbedaan nyata berdasarkan uji Duncan pada taraf nyata $\alpha=5 \%$ 
dipanen antara daun dan batang menunjukkan pola yang serupa yaitu bobot daun selalu lebih banyak dari bobot batang yang dipanen. Interval panen 2 dan 3 bulan sekali rata-rata menunjukkan persentase bobot daun yang lebih rendah dari interval panen 1 bulan. Interval panen 2 dan 3 bulan sekali rata-rata menunjukkan persentase bobot batang yang lebih tinggi dari interval panen 1 bulan sekali. Hal ini menunjukkan kecenderungan interval panen yang lebih lama mengalokasikan asimilat pada batang daripada daun.

Panen pada umur 3 BST menunjukkan perbedaan nyata pada bobot kering batang, tetapi tidak berbeda pada bobot basah batangnya. Begitu pula dengan panen pada umur 4 BST menunjukkan perbedaan nyata pada bobot kering daun, tapi tidak berbeda nyata pada bobot basah daun (Tabel 10). Hal ini disebabkan karena kadar air pada interval panen yang singkat lebih tinggi dari kadar air pada interval panen yang lama. Kadar air batang pada panen umur 3 BST menunjukkan adanya perbedaan antara interval panen 1 bulan sekali dan 3 bulan sekali, dimana interval panen 3 bulan sekali menghasilkan batang dengan kadar air yang lebih rendah dari interval panen 1 bulan sekali (Tabel 11). Interval panen yang singkat menghasilkan banyak tunas baru sehingga jaringan tanaman yang dipanen masih muda. Menurut $\mathrm{Hu}$ et al. (2017) jaringan tanaman yang masih muda memiliki kandungan air yang lebih tinggi, sehingga memungkinkan bobot basah yang lebih tinggi dari jaringan tanaman yang lebih tua.

Tabel 11. Nilai rata-rata interval panen terhadap kadar air panen

\begin{tabular}{cccccc}
\hline \multirow{5}{*}{$\begin{array}{c}\text { Interval } \\
\text { Panen } \\
\text { (bulan sekali) }\end{array}$} & \multicolumn{5}{c}{ Kadar Air (\%) } \\
\cline { 2 - 6 } & 2BST & 3BST & 4BST & 5BST & 6 6BST \\
\hline 1 & $86 \mathrm{a}$ & $84 \mathrm{a}$ & $87 \mathrm{a}$ & 86 & $83 \mathrm{a}$ \\
2 & $86 \mathrm{a}$ & $74 \mathrm{a}$ & $82 \mathrm{~b}$ & & $83 \mathrm{a}$ \\
3 & \multicolumn{5}{c}{ Batang } \\
\cline { 2 - 6 } & $89 \mathrm{a}$ & $93 \mathrm{a}$ & $89 \mathrm{a}$ & 92 & $90 \mathrm{a}$ \\
1 & $89 \mathrm{a}$ & $85 \mathrm{~b}$ & $90 \mathrm{a}$ & & $90 \mathrm{a}$ \\
2 & & & & $88 \mathrm{~b}$ \\
3
\end{tabular}

Keterangan: BST $=$ bulan setelah tanam

\section{Pigmen Daun}

Periode panen berpengaruh nyata terhadap kandungan klorofil a, karoten dan total klorofil, sedangkan dosis pupuk tidak berpengaruh nyata terhadap pigmen daun (Tabel 1). Interval panen 2 dan 3 bulan sekali meningkatkan kadar pigmen klorofil a dan karoten sebesar $13 \%$ dari interval panen 1 bulan sekali.Interval panen 3 dan 2 bulan sekali meningkatkan total klorofil sebanyak 12 dan $14 \%$ dibandingkan interval panen 1 bulan
(Tabel 12). Daun yang digunakan untuk analisis adalah daun nomor 3 dari bagian pucuk untuk setiap perlakuan. Interval panen yang lebih lama menyebabkan umur daun yang dianalisis menjadi lebih tua dari interval panen yang lebih singkat. Hal ini mengindikasikan bahwa pigmen berupa klorofil a, karoten dan total klorofil lebih tinggi pada jaringan daun yang lebih tua. Penelitian Maulid dan Laily (2015) menunjukkan hal serupa, daun kastuba yang berwarna merah maupun hijau memiliki kadar pigmen yang lebih tinggi pada daun yang berumur lebih tua.

Tabel 12. Nilai rata-rata interval panen terhadap kadar pigmen klorofil a, karoten dan total klorofil

\begin{tabular}{cccc}
\hline $\begin{array}{c}\text { Interval } \\
\text { Panen } \\
\text { (bulan sekali) }\end{array}$ & $\begin{array}{c}\text { Klorofil a } \\
\left(\mathrm{mg} \mathrm{g}^{-1}\right)\end{array}$ & $\begin{array}{c}\text { Karoten } \\
\left(\mathrm{mg} \mathrm{g}^{-1}\right)\end{array}$ & $\begin{array}{c}\text { Total } \\
\text { Klorofil } \\
\left(\mathrm{mg} \mathrm{g}^{-1}\right)\end{array}$ \\
\hline 1 & $0.25 \mathrm{~b}$ & $0.25 \mathrm{~b}$ & $0.89 \mathrm{~b}$ \\
2 & $0.29 \mathrm{a}$ & $0.29 \mathrm{a}$ & $1.04 \mathrm{a}$ \\
3 & $0.29 \mathrm{a}$ & $0.29 \mathrm{a}$ & $1.02 \mathrm{a}$ \\
\hline
\end{tabular}

Keterangan: Angka yang diikuti huruf yang berbeda pada kolom yang sama menunjukkan perbedaan nyata berdasarkan uji Duncan pada taraf nyata $\alpha=5 \%$

\section{KESIMPULAN}

Hasil penelitian menunjukkan bahwa dosis pupuk signifikan meningkatkan bobot basah total, bobot basah batang total serta parameter pertumbuhan berupa pertambahan tinggi tanaman, lebar tajuk dan jumlah cabang. Dosis pupuk 18 ton hektar-1 meningkatkan 33\% bobot basah total dan bobot basah batang total dibanding tanpa penggunaan pupuk kandang. Interval panen nyata menurunkan bobot basah daun total dan parameter pertumbuhan berupa jumlah daun, pertambahan tinggi tanaman, lebar tajuk, jumlah cabang, kadar air dan persentase daun batang. Interval panen 1 bulan sekali meningkatkan $31 \%$ bobot basah daun total dibanding dengan interval panen 3 bulan sekali. Interval panen nyata menurunkan kadar klorofil a, karoten dan total klorofil daun. Interval panen 3 bulan meningkatkan karoten dan klorofil a sebesar $13 \%$ serta meningkatkan total klorofil 12\%. Terdapat interaksi antara dosis pupuk dan interval panen pada parameter pertambahan tinggi tanaman umur 10 dan $26 \mathrm{MST}$.

\section{DAFTAR PUSTAKA}

Amrillah, M.S., R. Rusli, J. Fadraersada. 2015. Aktivitas tabir surya daun miana (Coleus artopurpureus L. Benth) secara in vitro. Jurnal Sains dan Kesehatan. 1(4): 168-174. 
Arifah, S.M. 2013. Aplikasi macam dan dosis pupuk kandang pada tanaman kentang. Jurnal Gamma. 8(2):80-85.

Esrita. 2012. Pengaruh pemangkasan tunas apikal terhadap pertumbuhan dan hasil kedelai (Glycine $\max (\mathrm{L})$. Merril). Bioplantae. 1(2):125-133.

Hu, J., F.A. Shah, W. Wu, Z. Cao, Q. Shu, S. Fu. 2017. Comparison of dynamic changes in endogenous hormone level, water content and water-soluble sugars in Camellia oleifera of different ages. Pak. J. Bot. 49(1):25-32.

Januwati, M., J. Pitono, Ngadimin. 1996. Pengaruh pemangkasan terhadap pertumbuhan dan produksi terna tanaman sambiloto. Warta Tumbuhan Obat Indonesia. 3(1):20-21.

Johnson, T. 1998. CRC Ethnobotany Desk Reference. CRC Press. New York, USA.

Maulid, R.R., A.N. Laily. 2015. Kadar total pigmen klorofil dan senyawa antosianin ekstrak kastuba (Euphorbia pulcherrima) berdasarkan umur daun. Prosiding Seminar Nasional Konservasi dan Pemanfaatan Sumber Daya Alam. Surakarta, 13 Januari 2015. hal 225-230.

Nugraheni, M., U. Santoso, Suparno, H. Wuryastuti. 2011. Potential of Coleus tuberosus as an antioxidant and cancer chemoprevention agent. International Food Research Journal. 18(4):1471-1480.

Paramitasari, D.R. 2011. Panduan Praktis Lengkap dan Menguntungkan Budi Daya Rimpang Jahe, Kunyit, Kencur, Temulawak. Cahaya Atma. Jakarta.

Prasetyo, R. 2014. Pemanfaatan berbagai sumber pupuk kandang sebagai sumber $\mathrm{N}$ dalam budidaya cabai merah (Capsicum annum L.) di tanah berpasir. Journal of Agro Science. 2(2):125-133.

Ragasa, C.Y., V.F. Templora, J.A. Rideout, 2001. Diastereomeric diterpens from Coleus blumei. Chem. Pharm. Bull. 49(7):927-929.

Rochayat, Y., A.C. Amalia, A. Nuraini. 2017. Pengaruh pemangkasan terhadap pertumbuhan, percabangan dan pembesaran bonggol tiga kultivar kamboja Jepang (Adenium arabicum). Jurnal Kultivasi. 16(2):382-387.
Saenong, M.S. 2016. Tumbuhan Indonesia potensial sebagai insektisida nabatu untuk mengendalikan hama kumbang bubuk jagung (Sitohilus spp.). Jurnal Litbang Pertanian. 35(3):131-142.

Saprudin. 2013. Pengaruh umur tanam pada saat pemangkasan terhadap pertumbuhan dan hasil ketimun (Cucumis sativus L.). Juristek. 1(2):51-62.

Scott, I.M., H. Jensen, J.G. Scott, M.B. Isman, J.T. Arnason, B.J.R. Philogene. 2003. Botanical insecticides for controlling agricultural pests: piperamides and the Colorado potato beetle Leptinotarsa decemlineata Say (coleopteran: chrysomelidae). Archieves of Insect Biochemistry and Physiology. 54:212-225.

Soni, H., A.K. Singhai. 2012. Recent update of the genus coleus: a review. Asian Journal of Pharmaceutical and Clinical Research. 5(1):12-17.

Sulistianingrum, R., A. Wachjar. 2015. Pertumbuhan tanaman cengkih (Syzygium aromaticum (L.) Merr Perr) belum menghasilkan pada berbagai dosis pupuk organik dan intensitas naungan. Bul. Agrohorti. 3(1):87-94.

Taufika, R., S.A.Aziz, M.Melati. 2016. Produksi flavonoid daun kemuning (Murraya paniculata L. Jack) pada dosis pupuk organik dan interval panen yeng berbeda. Bul. Littro. 27(1):27-36.

Usboko, A., A.A. Lelang, E.Y. Neonbeni. 2017. Pengaruh jenis dan dosis pupuk kandang terhadap pertumbuhan dan hasil tanaman kacang buncis (Phaseolus vulgaris L.). Jurnal Pertanian Konservasi Lahan Kering. 2(4):62064.

Winarto, W.P. 2003. Mahkota Dewa: Budidaya dan Pemanfaatan untuk Obat. Penebar Swadaya. Jakarta. 